\title{
Understanding Edward Muybridge: historical review of behavioral alterations after a 19th-century head injury and their multifactorial influence on human life and culture
}

\author{
Sunil Manjila, MD, ${ }^{1}$ Gagandeep Singh, $M D,{ }^{2}$ Ayham M. Alkhachroum, $M D,{ }^{2}$ and \\ Ciro Ramos-Estebanez, MD, PhD²,3
}

\begin{abstract}
Departments of ${ }^{1}$ Neurosurgery and ${ }^{2}$ Neurology, and ${ }^{3}$ Divisions of Neurocritical Care and Stroke, Neurological Institute, University Hospitals Case Medical Center, Cleveland, Ohio

Edward Muybridge was an Anglo-American photographer, well known for his pioneering contributions in photography and his invention of the "zoopraxiscope," a forerunner of motion pictures. However, this 19th-century genius, with two original patents in photographic technology, made outstanding contributions in art and neurology alike, the latter being seldom acknowledged. A head injury that he sustained changed his behavior and artistic expression. The shift of his interests from animal motion photography to human locomotion and gait remains a pivotal milestone in our understanding of patterns in biomechanics and clinical neurology, while his own behavioral patterns, owing to an injury to the orbitofrontal cortex, remain a mystery even for cognitive neurologists. The behavioral changes he exhibited and the legal conundrum that followed, including a murder of which he was acquitted, all depict the complexities of his personality and impact of frontal lobe injuries. This article highlights the life journey of Muybridge, drawing parallels with Phineas Gage, whose penetrating head injury has been studied widely. The wide sojourn of Muybridge also illustrates the strong connections that he maintained with Stanford and Pennsylvania universities, which were later considered pinnacles of higher education on the two coasts of the United States.
\end{abstract}

http://thejns.org/doi/abs/10.3171/2015.4.FOCUS15121

KEY WORDS orbitofrontal cortex; traumatic brain injury; photography; obsessive-compulsive; behavioral neurology; history of medicine; Muybridge; zoopraxiscope

$\mathrm{B}$ ORN in England on April 9, 1830, Edward Muybridge (Fig. 1) was a pioneer who analyzed sequential motion photographs using multiple cameras and invented the zoopraxiscope, a forerunner of motion pictures (Fig. 2). His biography is charged with passion, adventure, betrayal, murder, and genius, and it depicts his curiosity and observation of human locomotion, biomechanics, and clinical neurology. His remarkable contributions to photography and motion pictures are revered, while his head injury and its cognitive and legal implications are still a matter of debate. This article critically analyzes the proposed role of orbitofrontal and temporal cortex injury in his altered behavior and artistic excellence.

\section{Early Years}

Raised initially in Kingston-on-Thames, in Southwest
London, Edward Muybridge moved to San Francisco in 1852, where he started his career as a bookseller and established a prosperous bookshop. . $^{6,12,17}$

In 1860 , he planned a business trip to Europe on a ship, the Golden Age, but missed the boat. He then reserved a seat on a stagecoach and boarded along with other passengers for St. Louis. On the way, the driver lost control and the stagecoach descended a mountainside and crashed. ${ }^{6,12,17}$

\section{The Accident}

A telegraph message about a stagecoach accident in northeast Texas was published in the Sacramento Daily Union (August 6, 1860): ${ }^{20}$

The stage left Mountain Station with several passengers, besides the driver and Mr. Stout, a road-master, in the employ of the Overland Company, who was acting as conductor. On

SUBMITTED March 2, 2015. ACCEPTED April 22, 2015.

INCLUDE WHEN CITING DOI: 10.3171/2015.4.FOCUS15121.

DISCLOSURE The authors report no conflict of interest concerning the materials or methods used in this study or the findings specified in this paper. 


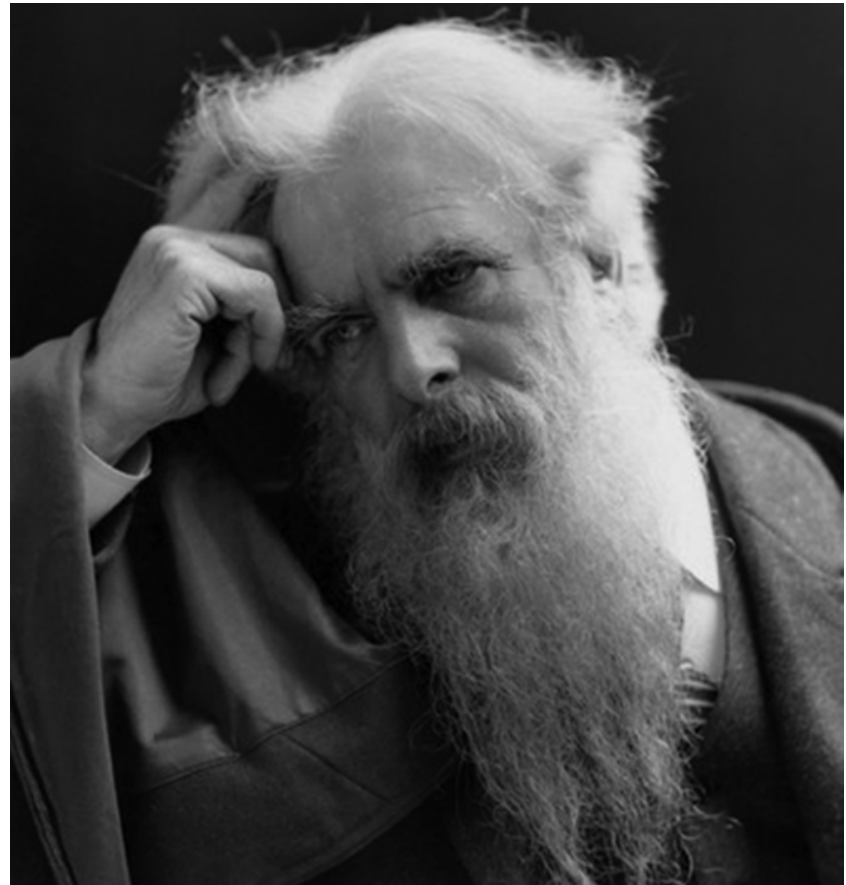

FIG. 1. Photograph showing E. Muybridge, 1900. Public domain.

leaving the stable, the driver cracked his whip and the horses immediately started on a run. When they arrived at the brow of the mountain the brakes were applied, but were found to be useless. In his efforts to stop the horses, the driver drove out off the road, and they came in collision with a tree, literally smashing the coach in pieces, killing one man ... and injuring every other person on the stage to a greater or less extent.

Muybridge was ejected from the vehicle and sustained a head injury. He was taken to Fort Smith, Arkansas, where he was treated for 3 months. ${ }^{6,12,17}$

\section{The Lesion}

At the time of his trial for murder over 10 years later, Muybridge made the following statement about the accident (San Francisco Chronicle, February 6, 1875):23

\begin{abstract}
A fellow passenger told me after I had recovered consciousness that after leaving that station we had traveled for probably half an hour-we were then just entering the Texas Cross-Timbers. The mustangs ran away. The driver was unable to control them. Just as we were getting to the Timbers I remarked that the best plan would be for us to get out of the back of the stage, because I saw that an accident would take place. He told me that I took out my knife to cut the canvas back of the stage, and was preparing to leave when the stage ran against either a rock or a stump and threw me out against my head.
\end{abstract}

Muybridge claimed no recollection of the accident. When he recovered, he reported that each eye had an individual image such that if he saw a man seated in front of him, he would see double.6,12,17 Additionally, there were indications of impaired smell and taste. From this evidence, Muybridge had endured a closed brain injury. At the time, there were obviously no means to image his brain or perform any neuropsychological testing. His visual symptoms and loss of smell and taste were attributed

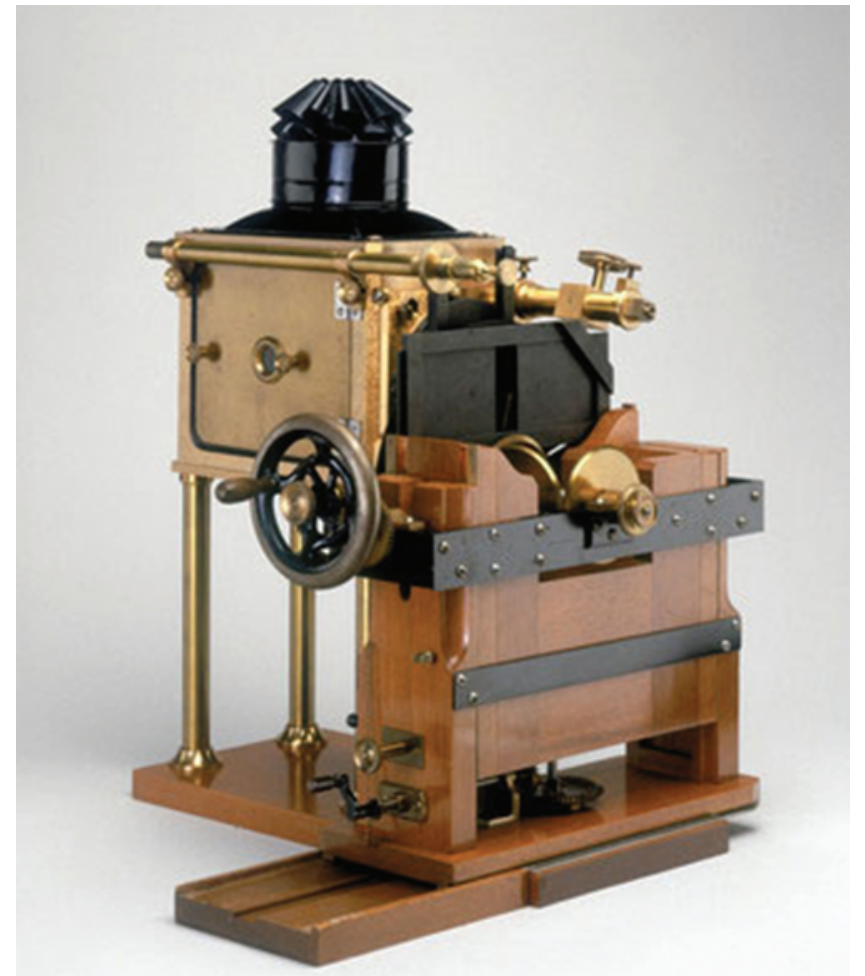

FIG. 2. Muybridge's zoopraxiscope, 1880. Courtesy of the National Media Museum/Science \& Society Picture Library.

to an injury localized to the orbitofrontal cortex. ${ }^{9}$ Besides, the emotional instability, aggressiveness, and possessiveness that developed after the accident also suggested frontal lobe involvement. ${ }^{5}$ Aggressive behavior and impulsivity are the common symptoms in orbitofrontal cortex injury. ${ }^{5}$ Of note, he changed his name several times, modifying the spelling each time subsequent to the stagecoach accident. There are reports that his name changed from Edward Muggeridge, to Muggridge, to Muygridge, and finally to Muybridge; however his tombstone bore another name, Maybridge. Apparently, while working in Central America in his later life, documenting coffee production, he used the name Eduardo Santiago Muybridge. His first name also underwent a similar change, to Eadweard (apparently after the name of King Edward I on the coronation stone re-erected in 1850), which followed him to his grave. This strange behavior of rechristening himself was a distinct quirk in his personality. This behavior might suggest baseline grandiose thoughts, which would intensify in the setting of a frontotemporal injury. In addition, he may have developed obsessive-compulsive traits in the setting of an orbitofrontal-striatal network lesion. ${ }^{18}$

\section{Career Change}

After the stagecoach accident, Muybridge left for England and received treatment from Sir William Withey Gull, 1st Baronet of Brook Street (1816-1890). This famed neurologist was Queen Victoria's personal physician and was also well known for his original contributions to the understanding of tabes dorsalis, myxedema, and anorexia nervosa. He took care of patients at Guy's Hospital in 
London. Although Muybridge stayed in England for 5 or 6 years, little is known about his relationship with Gull. Sir William prescribed outdoor activities for Muybridge's rehabilitation. A keen observer of the personality changes unfolding before his eyes, Gull recommended that Muybridge consider photography as a new profession.

Once he mastered the wet-collodion process, Muybridge returned to America. ${ }^{6,12,17}$ Although he had no memories of the days preceding the accident or the event itself, he had a sense of time being stopped and suspended with his neardeath experience., $, 12,17 \mathrm{He}$ was moving fast and suddenly time stopped. ${ }^{6,12,17}$ This very much influenced his perception of the surrounding world and his ability to express himself artistically. He started observing animals and humans in motion, capturing what the human eye could not distinguish as separate or fractionated movements. Then, back in America, he began to explore time through artistically deconstructing it in photographs to assemble it back into its regular flow through motion pictures. His reputation as a photographer reached new heights after his photography of Yosemite and San Francisco in 1867. His Yosemite Valley work involved images taken from challenging angles that offered both a thrill and an adventure. To the viewer it was an enigma to capture nature in such an unorganized and disjointed, angular way. He loved chaos and the Darwinian theory that destroys the peace of divine order and opens the door to the age of anxiety. ${ }^{24} \mathrm{He}$ also enjoyed taking photographs of the defiant nature of the $\mathrm{Na}-$ tive Americans; one picture in particular has a man pointing an arrow directly at the camera.

\section{Murder, Legal Battle, Acquittal, and Frontal Cortex}

Muybridge married a 21-year-old divorcee, Flora Shallcross Stone. They had a son, whose paternity Muybridge disputed, once he learned of her affair with drama critic Major Harry Larkyns. Muybridge shot and killed Larkyns in 1874, and Muybridge's attorney, Mr. Pendergast, pled insanity due to the defendant's brain injury. ${ }^{6,12,17}$

Sworn testimonies reported in newspapers during the trial depicted personality changes after Muybridge's accident: ${ }^{6,12,17}$

Silas Selleck, photographer, called and sworn-Resides in San Francisco; known Muybridge for 26 or 27 years. Muybridge, from 1852 to " 1867 , was a genial, pleasant and quick business man; after his return from Europe he was very eccentric, and so very unlike his way before going; the change in his appearance was such that I could scarcely recognize him after his return. ${ }^{21}$ (Sacramento Union, February 5, 1875)

Silas Selleck testified that before Muybridge's trip East he was active, energetic, strict in all his dealings, open and candid. When he came back he had changed entirely. He was eccentric, peculiar, and had the queerest of odd notions, so much so that he seemed like a different man. ${ }^{23}$ (San Francisco Chronicle, February 6, 1875)

M. Gray, called and sworn-Resides in San Francisco; been there twenty years. Knew the defendant for twenty years intimately. Remember his going to Europe in $1859 . .$. "Was much less irritable than after his return; was much more careless in dress after his return; was not as good a businessman. Has not been the same man in any respect since." ${ }^{21}$ (Sacramento Union, February 5, 1875)

J. G. Easland testified that he had been intimately acquainted with Muybridge for a number of years before and after his European trip. Heard of the accident to him on the trip. After his return I noticed certain eccentricities of speech, manner, and action, and my impression formed thereof. I thought the change was such that had I heard of this killing before the accident it would have surprised me, but occurring after it did not. ${ }^{23}$ (San Francisco Chronicle, February 6, 1875)

The change of personality that moved him to take risky decisions was described in Rulofsan's testimony:

He had seen frequent indications of unsoundedness of mind in the defendant. The witness then related strange things, which Muybridge had done during the period of his acquaintance with him. One thing was, that while Muybridge was a strictly honest man, he would make a bargain or contract with one at night and next morning go back on it in tote and make a new contract. These idiosyncrasies he had noticed within two years. The witness said he could go on and fill whole volumes with the peculiar things Muybridge had done. Among the strange freaks which Muybridge had committed was to have his picture taken on a rock at Yosemite valley, where a biscuit, if slightly tilted, would have fallen down 2,000 feet..$^{23}$ (San Francisco Chronicle, February 6, 1875)

Subsequently, Muybridge's case was ruled as justifiable homicide. The San Francisco Chronicle described the outcome (February 7, 1875):22

The jury discarded entirely the theory of insanity, and meeting the case on the bare issue left, acquitted the defendant on the ground that he was justified in killing Larkyns for seducing his wife. This was directly contrary to the charge of the Judge, but the jury do not mince the matter, or attempt to excuse the verdict. They say that if their verdict was not in accord with the law of the books, it is with the law of human nature; that, in short, under similar circumstances they would have done as Muybridge did, and they could not conscientiously punish him for doing what they would have done themselves.

Muybridge's reaction was emotionally prodigious after the verdict (San Francisco Chronicle, February 7, 1875):22

At the sound of the last momentous words a convulsive gasp escaped the prisoner's lips, and he sank forward from his chair. The mental and nervous tension that had sustained him for days of uncertain fate was removed in an instant; and he became as helpless as a new-born babe. Mr. Pendegast caught him in his arms and thus prevented his falling to the floor, but his body was limp as a wet cloth. His emotion became convulsive and frightful. His eyes were glassy, his jaws set and his face livid. The veins of his hands and forehead swelled out like whipcord. He moaned and wept convulsively, but uttered no word of pain or rejoicing. Such a display of overpowering emotion has seldom, if ever, been witnessed in a Court of justice.... He rocked to and fro in his chair. His face was absolutely horrifying in its contortions as convulsion succeeded convulsion.... Pendegast begged Muybridge to control himself and thank the jurymen for their verdict. He arose to his feet, and tried to speak, but sank back in another convulsion. He was carried out of the room by Pendegast and laid on a lounge in the latter's office.

Lesion studies and virtual lesion paradigms have generated abundant information concerning the behavioral role of diverse anatomical areas. Phineas Gage's case study and Oppenheim's neuropsychological correlates of orbitofrontal and mesial frontal lesions ${ }^{15,16}$ represent aca- 
demic milestones in our understanding of neuropsychology. Gage's lesion was thoroughly characterized by Dr. Harlow's ${ }^{5}$ initial description and enriched with subsequent contributions. ${ }^{3,19}$ In many ways, he shared Muybridge's behavioral changes. Similar to Muybridge, preceding his accident while working on a railroad, Gage had always been regarded as a hardworking, capable, and well-balanced man. However, after the accident his physician (Dr. Harlow) described him as follows: "He is fitful, irreverent, indulging at times in the grossest profanity (which was not previously his custom), manifesting but little deference for his fellows, impatient of restraint or advice when it conflicts with his desires." 5 These common behavioral changes lead to a comparison between Gage's well-described left penetrating orbitofrontal cortex lesion and Muybridge's closed traumatic brain injury. $3,5,15,16,19$

\section{Did Muybridge's Injury Impact His Career?}

It has been proposed that Muybridge's behavioral changes resembled certain aspects of clinical progression in frontotemporal dementia. ${ }^{11}$ These patients develop atrophy in the orbitofrontal cortex. As a consequence, in some cases they seem to develop artistic expression. The purported explanation invokes a disinhibited expression of their emotions through art. Muybridge's disinhibition may have possibly unveiled his artistic and inventive genius. His taking up remote areas for assignments and taking tens of thousands of pictures of animals in motion illustrate his risk-taking behavior and obsessive-compulsive nature. ${ }^{18}$

Muybridge recorded common human movement while performing diverse tasks. As customary in his time, he assembled men above women. ${ }^{4}$ However, he notably portrayed the uncovered before the dressed figures, in a period when controversy about nudity was significant. One wonders if this trait stemmed from his uninhibited frontal cortex. $^{4}$

\section{Original Contributions to Photography}

In an era that predated flexible perforated film strips, Muybridge started his photography training with wet collodium but transitioned to a novel dry-plate approach through a series of large cameras with glass plates in a line, timed with a clockwork device in a brass-and-wood apparatus. ${ }^{1,6,8,12,17}$ The images were then copied onto a disc as silhouettes and viewed in a zoopraxiscope (i.e., animal action viewer), a forerunner of motion pictures or cinematography. $1,6,8,12,17$

During the period 1883-1886, Muybridge took well over 100,000 photographs, 20,000 of which were reproduced as 781 plates in the seminal work Animal Locomotion, London 1887 (Fig. 3), a masterpiece monograph in 11 volumes produced under the auspices of the University of Pennsylvania and published in an era that predated flexible perforated film strips. At this time, his collaboration with Dr. Francis Dercum yielded the first films characterizing neurological patients?

Muybridge was an ingenious inventor who enjoyed an outstanding career in motion photography. He secured several patents during the span of his career. One was re-

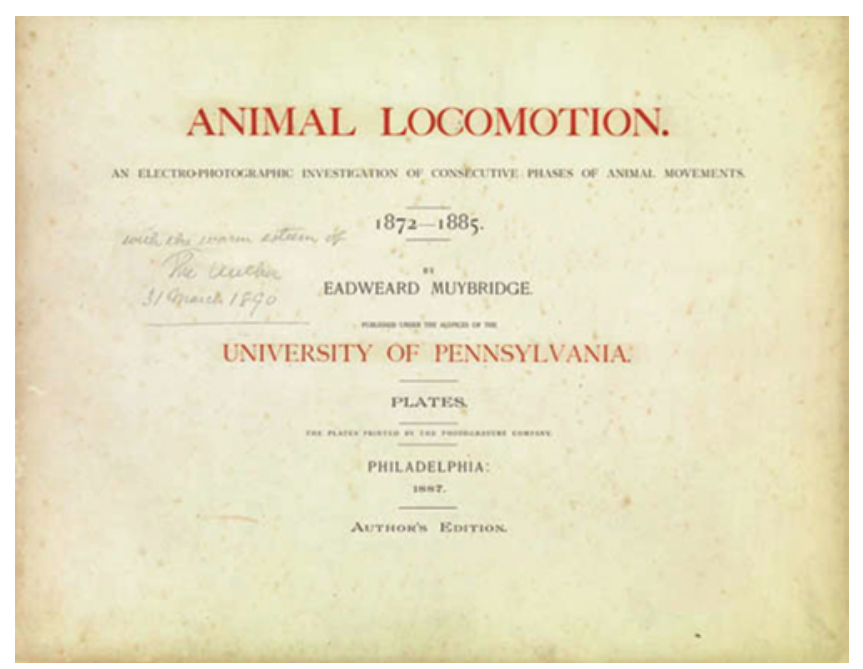

FIG. 3. Photograph of the cover of Muybridge's book, Animal Locomotion: an Electro-Photographic Investigation of Connective Phases of Animal Movements, Philadelphia: 1887. Public domain. Courtesy of the University of Pennsylvania archives.

lated to plate printing (an apparatus and improved method for plate printing); another was for the zoopraxiscope, one of the earliest motion picture projectors. ${ }^{24} \mathrm{He}$ did several displays using the zoopraxiscope, giving lectures over the course of 15 years in the United States and England. His exhibition to the paying public at the 1893 Chicago World Columbian Exposition's Midway Plaisance is considered the first "commercial movie theater display."

\section{Connections with Stanford and University of Pennsylvania}

Leland Stanford was a prominent racehorse owner, had served as Governor of California in 1872, and later founded Stanford University. He believed in "unsupported transit" in the trot and gallop, which meant that, while galloping, 4 of the horse's legs were, at a given moment, off of the ground. He hired Muybridge, who, with his zoopraxiscope, confirmed that this was the case in Stanford's mare Occident's gallop (Fig. 4). He also took a series of photos at Stanford's Palo Alto Stock Farm by placing numerous large glass-plate cameras in a line along the edge of the track. The shutter of each was triggered by a thread as the horse passed and the path was lined with cloth sheets to reflect as much light as possible. In 1878, Muybridge made a famous 13 -part, $360^{\circ}$ photographic panorama of San Francisco, to be presented to Leland Stanford's wife.

In 1882, Stanford financed and published the book The Horse in Motion, illustrated with Muybridge's photographs (Fig. 5). J. D. B. Stillman wrote the accompanying text. Notably, Muybridge was merely credited as Stanford's employee. This led to a quarrel with Stanford, resulting in Muybridge leaving the west coast and relocating to the University of Pennsylvania.

Eventually, Muybridge received a grant from the University of Pennsylvania, funding his work from 1883 to 1886. He described his goals in a prospectus: ${ }^{10}$

An extended series of experiments will be made for accurately recording the successive attitudes, oscillations and movements 


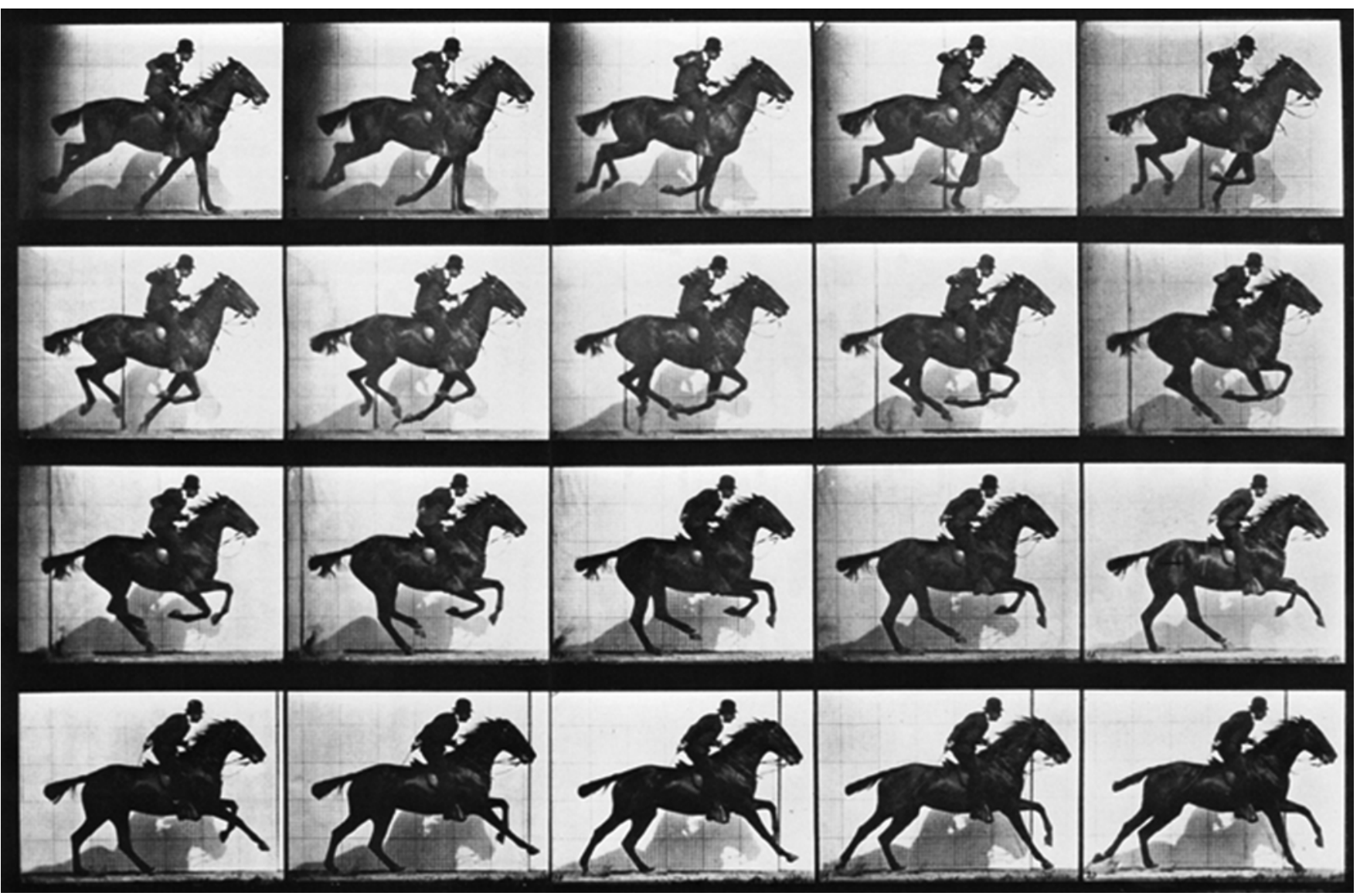

FIG. 4. "Horse Galloping Saddled Clothed Male Rider" by E. Muybridge, Plate 628. Courtesy of Karl Jahnke.

of the human body in health and disease. These illustrations, I am assured by many eminent physicians and experimental physiologists, will be of immense value to that large class of human beings suffering from bodily deformities and chronic diseases of the joints.

While supported by Philadelphia neurologist Francis Dercum (1856-1931), he captured motion in more than 100,000 images of animals and people, yielding the publication of his Human and Animal Locomotion in 1887.13,14 Volume 8 included motion pictures depicting neurological patients (Videos 1-9). , 12,17

VIDEO 1. Choreo-ballistic movements, in a motion picture by $\mathrm{E}$. Muybridge. Plate 557. Public domain, courtesy of Karl Jahnke. Click here to view with Media Player. Click here to view with Quicktime.

VIDEO 2. Descending stairs. Pelvic tilt, shown in a motion picture by E. Muybridge. Plate 129. Public domain, courtesy of Karl Jahnke. Click here to view with Media Player. Click here to view with Quicktime.

VIDEO 3. Normal ascending gait demonstrating pelvic movements, posture, and arm swing by E. Muybridge. Plate 90. Public domain, courtesy of Karl Jahnke. Click here to view with Media Player. Click here to view with Quicktime.

VIDEO 4. Scissoring gait with spasticity; note hip and knee positions bilaterally by E. Muybridge. Plate 561. Public domain, courtesy of Karl Jahnke. Click here to view with Media Player. Click here to view with Quicktime.

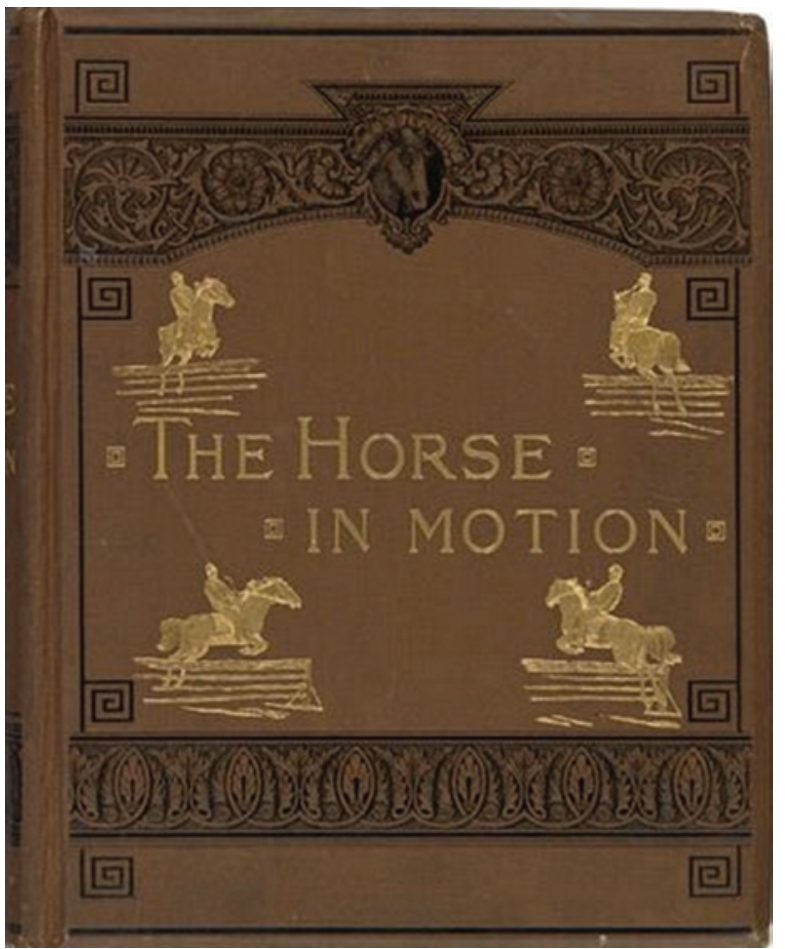

FIG. 5. Front cover of The Horse in Motion by J. D. B. Stillman. Boston: James R. Osgood and Company, 1882. Muybridge provided the illustrations. Public domain. 


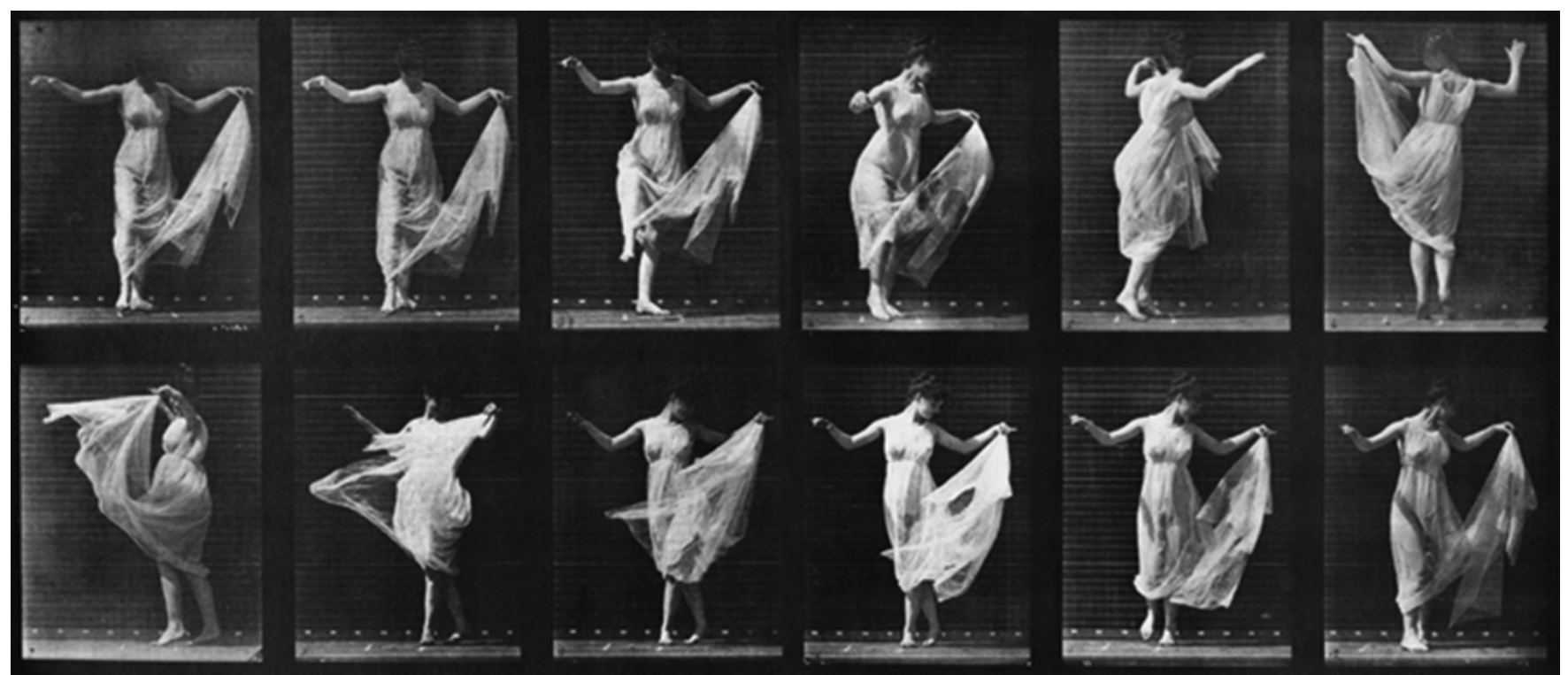

FIG. 6. "Woman Dancing (Fancy)," plate 187 from Animal Locomotion, 1887 by E. Muybridge. Courtesy of Karl Jahnke.
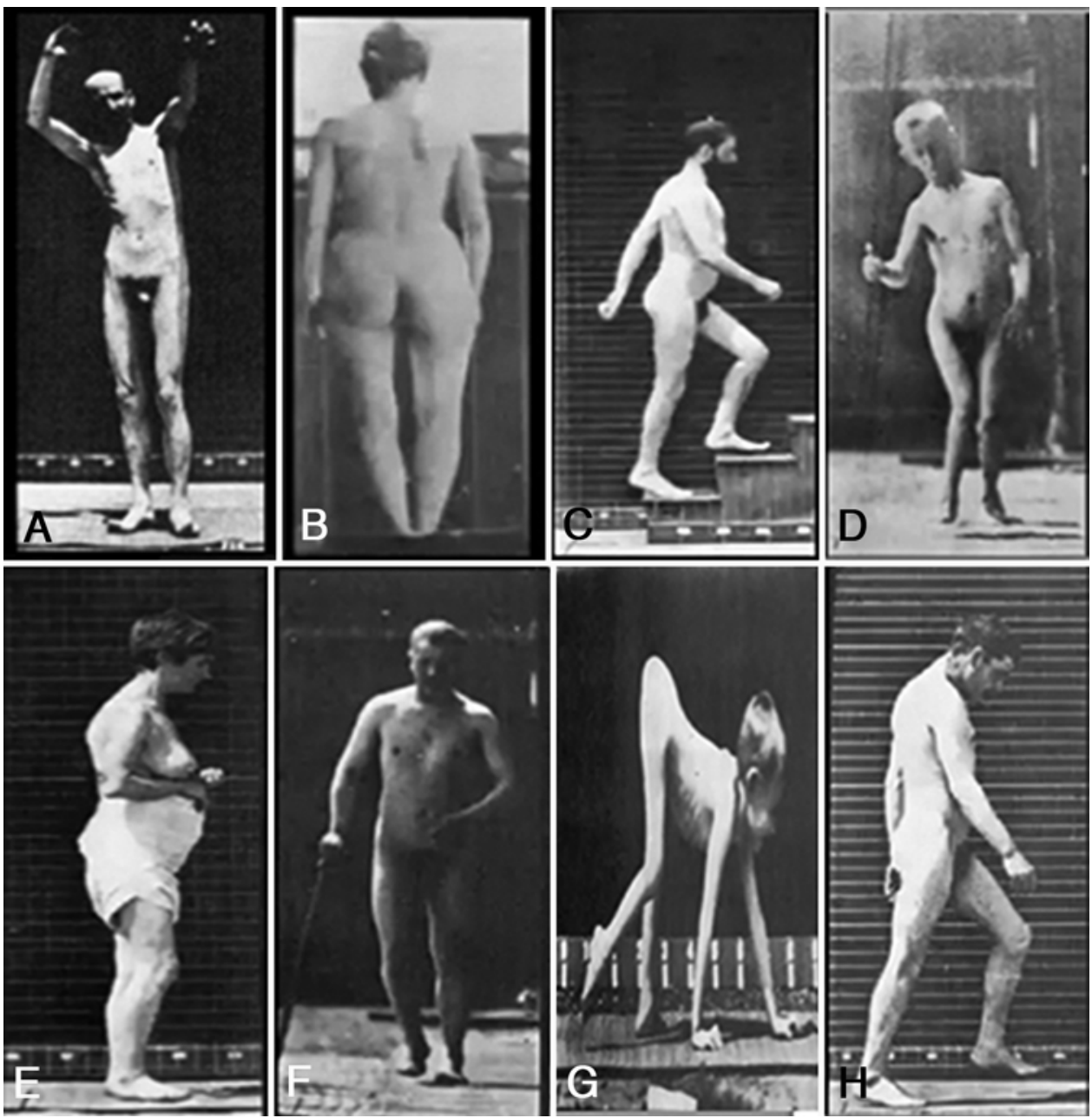

FIG. 7. Photographs of neurological patients during Muybridge's period at University of Pennsylvania. Courtesy of Karl Jahnke. 
VIDEO 5. Spastic gait in a woman, as seen in a motion picture by $\mathrm{E}$. Muybridge. Plate 542. Public domain, courtesy of Karl Jahnke. Click here to view with Media Player. Click here to view with Quicktime.

VIDEO 6. Man with aided (cane), left spastic hemiparesis gait with classic circumduction of left lower-extremity by E. Muybridge. Plate 552. Public domain, courtesy of Karl Jahnke. Click here to view with Media Player. Click here to view with Quicktime.

VIDEO 7. Leap-frogging child with a classic paretic gait by $\mathrm{E}$. Muybridge. Plate 539. Public domain, courtesy of Karl Jahnke. Click here to view with Media Player. Click here to view with Quicktime.

VIDEO 8. Left high-stepping gait as observed by E. Muybridge. Plate 549. Public domain, courtesy of Karl Jahnke. Click here to view with Media Player. Click here to view with Quicktime.

VIDEO 9. Rowing man: video depicting classic posture and coordinated body movements, recorded by E. Muybridge. Plate 327. Public domain, courtesy of Karl Jahnke. Click here to view with Media Player. Click here to view with Quicktime.

\section{Contributions to the Arts}

Muybridge's work influenced Impressionist Edgar Degas, ${ }^{4}$ among other artists. For example, Muybridge's "Woman Dancing (Fancy)," plate 187 of Animal Locomotion, 1887, has been discussed as a precursor of Degas' evolution from a stationary mode to an expressive ballet picturing movement (Fig. 6). ${ }^{4}$

More notably, Muybridge's influence expands to the development of the movie industry in conjunction with the Lumière brothers, Thomas Edison, Dickson, and ÉtienneJules Marey. 2,6,12,17,25 Not only did he characterize motion in animals, but also human physiological and pathological states. As a curiosity, he showcased a tape with the first filmed kiss. ${ }^{6,12,17}$ The motion pictures of Muybridge depicting human locomotion served as a template for clinical neurologists, especially those interested in movement disorders (Fig. 7 panels A-H correspond to Videos 1-8).

\section{Conclusions}

In summary, Edward Muybridge was an enterprising young bookseller who morphed into a revolutionary genius. There is arguably strong evidence suggestive of the role that his closed traumatic brain injury played in his behavioral changes. This manuscript describes how his new personality traits might have impacted an outstanding career of discovery in photography, biomechanics, and clinical neurology in the late 19th century.

\section{References}

1. Aubert G: Neurological illustration from photography to cinematography. Handb Clin Neurol 95:289-302, 2010

2. Braun M: Picturing Time: The Work of Etienne-Jules Marey (1830-1904). Chicago: University of Chicago Press, 1992

3. Damasio H, Grabowski T, Frank R, Galaburda AM, Damasio AR: The return of Phineas Gage: clues about the brain from the skull of a famous patient. Science 264:1102-1105, 1994

4. Devonyar J, Kendall R: Degas and the Ballet: Picturing Movement. London: Royal Academy Books, 2011

5. Harlow JM: Recovery of an iron rod through the head. Publ Mass Med Soc 2:327-347, 1868

6. Hendricks G: Eadweard Muybridge: The Father of the Motion Picture. New York: Grossman Publishers, 1975
7. Lanska DJ: The Dercum-Muybridge collaboration for sequential photography of neurologic disorders. Neurology 81:1550-1554, 2013

8. Marey J: The history of chronophotography, in Annual Report of the Board of Regents of the Smithsonian Institution. Washington DC: Smithsonian Institution, 1901, pp 317-341

9. McAllister TW: Neuropsychiatric sequelae of head injuries. Psychiatr Clin North Am 15:395-413, 1992

10. McVaugh MR: Francis X. Dercum and animal locomotion. Caduceus 3:1-35, 1987

11. Miller BL, Cummings J, Mishkin F, Boone K, Prince F, Ponton $\mathrm{M}$, et al: Emergence of artistic talent in frontotemporal dementia. Neurology 51:978-982, 1998

12. Mozley AV: Introduction, in Muybridge E: Muybridge's Complete Human and Animal Locomotion: All 781 Plates from the 1887 Animal Locomotion. New York: Dover, 1979, Vol. 1, pp 1-38

13. Muybridge E: Animal Locomotion: An Electro-Photographic Investigation of Consecutive Phases of Animal Movements, 1872-1885. Philadelphia: University of Pennsylvania, 1887

14. Muybridge E: Muybridge's Complete Human and Animal Locomotion: All 781 Plates from the 1887 Animal Locomotion. New York: Dover, 1979, Vol 2, pp 1081-1139

15. Oppenheim H: Zur Pathologie der Grosshirngeschwülste. Arch Psychiatrie Nervenkrankh 21:560-587, 705-545, 1890

16. Oppenheim H: Zur Pathologie der Grosshirngeschwülste. Arch Psychiatrie Nervenkrankh 22:27-72, 1891

17. Prodger P: Time Stands Still: Muybridge and the Instantaneous Photography Movement. Oxford, UK: Oxford University Press, 2003

18. Rasmussen SA, Eisen JL, Greenberg BD: Toward a neuroanatomy of obsessive-compulsive disorder revisited. Biol Psychiatry 73:298-299, 2013

19. Ratiu P, Talos IF, Haker S, Lieberman D, Everett P: The tale of Phineas Gage, digitally remastered. J Neurotrauma 21:637-643, 2004

20. Sacramento Daily Union: Letter from St. Louis. August 6, 1860; 1 (col. 4)

21. Sacramento Union: The Larkyns-Muybridge tragedy. February 5,1875

22. San Francisco Chronicle: "The higher law." Muybridge acquitted of the charge of murder. February 7, 1875; 8 (col. 3)

23. San Francisco Chronicle: The Muybridge trial. February 6, 1875

24. Shimamura AP: Muybridge in motion: travels in art, psychology and neurology. History of Photography 26:341-350, 2002

25. Spehr P: Edison, Dickson and the chronophotographers: creating an illusion, in Albera F, Gaudreault A, Braun M (eds): Stop Motion, Fragmentation of Time. Lausanne, Switzerland: Payot, 2002, pp 189-221

\section{Author Contributions}

Conception and design: Ramos-Estebanez, Manjila. Acquisition of data: all authors. Analysis and interpretation of data: all authors. Drafting the article: all authors. Critically revising the article: Ramos-Estebanez. Reviewed submitted version of manuscript: Ramos-Estebanez, Singh, Alkhachroum. Approved the final version of the manuscript on behalf of all authors: RamosEstebanez.

\section{Videos}

Video 1, Media Player. http://mfile.akamai.com/21490/wmv/ digitalwbc.download.akamai.com/21492/wm.digitalsource-naregional/focus15-121_video_1_NEW.asx. 
Video 1, Quicktime. http://mfile.akamai.com/21488/mov/ digitalwbc.download.akamai.com/21492/qt.digitalsource-global/ focus15-121_video_1_NEW.mov.

Video 2, Media Player. http://mfile.akamai.com/21490/wmv/ digitalwbc.download.akamai.com/21492/wm.digitalsource-naregional/focus15-121_video_2_NEW.asx.

Video 2, Quicktime. http://mfile.akamai.com/21488/mov/ digitalwbc.download.akamai.com/21492/qt.digitalsource-global/ focus15-121_video_2_NEW.mov.

Video 3, Media Player. http://mfile.akamai.com/21490/wmv/ digitalwbc.download.akamai.com/21492/wm.digitalsource-naregional/focus15-121_video_3_NEW.asx.

Video 3, Quicktime. http://mfile.akamai.com/21488/mov/ digitalwbc.download.akamai.com/21492/qt.digitalsource-global/ focus15-121_video 3 NEW.mov.

Video 4, Media Player. http://mfile.akamai.com/21490/wmv/ digitalwbc.download.akamai.com/21492/wm.digitalsource-naregional/focus15-121_video_4_NEW.asx.

Video 4, Quicktime. http://mfile.akamai.com/21488/mov/ digitalwbc.download.akamai.com/21492/qt.digitalsource-global/ focus15-121_video_4_NEW.mov.

Video 5, Media Player. http://mfile.akamai.com/21490/wmv/ digitalwbc.download.akamai.com/21492/wm.digitalsource-naregional/focus15-121_video_5_NEW.asx.

Video 5, Quicktime. http://mfile.akamai.com/21488/mov/ digitalwbc.download.akamai.com/21492/qt.digitalsource-global/ focus15-121_video_5_NEW.mov.

Video 6, Media Player. http://mfile.akamai.com/21490/wmv/ digitalwbc.download.akamai.com/21492/wm.digitalsource-naregional/focus15-121_video_6_NEW.asx.

Video 6, Quicktime. http://mfile.akamai.com/21488/mov/ digitalwbc.download.akamai.com/21492/qt.digitalsource-global/ focus15-121_video_6_NEW.mov.

Video 7, Media Player. http://mfile.akamai.com/21490/wmv/ digitalwbc.download akamai.com/21492/wm.digitalsource-naregional/focus15-121_video_7_NEW.asx.

Video 7, Quicktime. http://mfile.akamai.com/21488/mov/ digitalwbc.download.akamai.com/21492/qt.digitalsource-global/ focus15-121_video_7_NEW.mov.

Video 8, Media Player. http://mfile.akamai.com/21490/wmv/ digitalwbc.download akamai.com/21492/wm.digitalsource-naregional/focus15-121_video_8_NEW.asx.

Video 8, Quicktime. http://mfile.akamai.com/21488/mov/ digitalwbc.download.akamai.com/21492/qt.digitalsource-global/ focus15-121_video_8_NEW.mov.

Video 9, Media Player. http://mfile.akamai.com/21490/wmv/ digitalwbc.download.akamai.com/21492/wm.digitalsource-naregional/focus15-121_video_9_NEW.asx.

Video 9, Quicktime. http://mfile.akamai.com/21488/mov/ digitalwbc.download.akamai.com/21492/qt.digitalsource-global/ focus15-121_video_9_NEW.mov.

\section{Correspondence}

Ciro Ramos-Estebanez, Case Western Reserve University, 11100 Euclid Ave., Cleveland, OH 44106. email: ciro.ramosestebanez@ uhhospitals.org. 